\title{
Źródta stresu zawodowego a sposoby radzenia sobie w sytuacjach stresogennych pielęgniarek pracujących na wybranych oddziałach szpitalnych - doniesienia wstępne*
}

\section{Occupational stress and coping strategies among nurses - preliminary research}

\author{
Katarzyna Kwiecień-Jaguś1 ${ }^{\bowtie}$, Wioletta Mędrzycka-Dąbrowskaํ, Anna Małecka-Dubiela² \\ ${ }^{1}$ Gdański Uniwersytet Medyczny, Zakład Pielęgniarstwa Anestezjologicznego i Intensywnej Opieki, ul. Dębinki 7, 80-211 Gdańsk \\ Medical University of Gdańsk, Department of Anaesthesiology and Intensive Care \\ ${ }^{2}$ Gdański Uniwersytet Medyczny, Zakład Pielęgniarstwa Ogólnego, ul. Dębinki 7, 80-211 Gdańsk \\ Medical University of Gdańsk, Department of General Nursing \\ $\triangle$ kasiad124@gumed.edu.pl
}

\begin{abstract}
Introduction: Stress is inherent in the work of medical staff at health care establishments. The problem of stress in the working environment of nursing staff becomes more and more important in the context of increasing staff shortages and insufficient support from colleagues and employers.

The aim of this paper was to analyse and compare the stressors associated with the day-to-day work of nursing staff and to examine the relationship between stress and the way of coping with it. Materials and methods: The study was anonymous and voluntary. The research included 106 nurses from different types of wards. The study used a questionnaire and two standardized research tools: Nursing Stress Scale and Brief Cope-28 Scale. All the statistical calculations were performed on the basis of IBM SPSS 20 software and an Excel spreadsheet.
\end{abstract}

Results: Among the multiple stress factors in the work environment, the most typical stressors facing nursing staff were: death and dying (M 15.19; SD \pm 3.10 ), workload ( $M$ 14.73; SD \pm 3.13 ), and conflicts between nurses and physicians ( $M$ 10.42; $\mathrm{SD} \pm 1.85$ ). The research showed a significant relationship between stress and the place of work $(H=13.99 ; \mathrm{p}<0.05)$. The results showed that nurses very often use positive mechanisms to minimize stress like planning (M 6.31; SD \pm 1.31 ) or positive reframing (M 5.84; $\mathrm{SD} \pm 1.49$ ). Another analysis indicated a strong relationship between age and resorting to spirituality and social support. Conclusion: Nursing work is characterized by a very high level of stress. Some of the stress factors like nurse-physician conflicts may be reduced by better management and work organization. Keywords: stress; coping styles; nursing staff; risk factors; workload; workplace.

\begin{abstract}
ABSTRAKT
Wstęp: Stres jest nieodłącznym elementem pracy personelu medycznego. Problem stresu w środowisku pracy personelu pielęgniarskiego nabiera znaczenia w kontekście coraz częstszych braków kadrowych, a także braku wsparcia ze strony pracodawców.

Celem pracy była analiza czynników stresogennych związanych z codzienną pracą personelu pielęgniarskiego wybranych oddziałów szpitalnych oraz zbadanie związku pomiędzy stresem a sposobami radzenia sobie z nim.

Materiały i metody: W badaniu wykorzystano kwestionariusz wywiadu oraz dwa wystandaryzowane narzędzia badawcze: Nursing Stress Scale i Brief Cope-28 Scale. W badaniu prowadzonym anonimowo dobrowolny udział wzięło 110 pielęgniarek. Obliczenia statystyczne wykonano w oparciu o program komputerowy IBM SPSS 20 oraz arkusz Excel.

Wyniki: Analizy statystyczne wykazały, że spośród wielu czynników stresogennych w środowisku pracy personelu pielęgniarskiego największe źródło stresu stanowiły: śmierć i umieranie
\end{abstract}

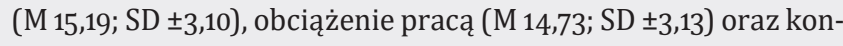
flikty na linii pielęgniarka-lekarz (M 10,42; SD $\pm 1,85$ ). Wykazano istotną statystycznie zależność pomiędzy miejscem zatrudnienia a poziomem odczuwanego stresu $(H=13,99$; $p<0,05)$. W sytuacjach stresowych personel pielęgniarski najczęściej odnosił się do aktywnych sposobów radzenia sobie ze stresem, w tym rozwiązywania sytuacji stresowych poprzez planowanie $(M \quad 6,31$; SD $\pm 1,31)$ oraz pozytywnego przewartościowania (M 5,84; SD $\pm 1,49)$. Dalsze analizy wykazały związek pomiędzy wiekiem a uciekaniem do spraw duchowych lub poszukiwaniem wsparcia społecznego.

Wnioski: Praca personelu pielęgniarskiego nacechowana jest wysokim poziomem stresu, który w dużym stopniu zależy od profilu medycznego danego oddziału. Część czynników stresogennych można zmniejszyć poprzez poprawę organizacji pracy, zwłaszcza w kontekście współpracy pielęgniarki z lekarzem. Słowa kluczowe: stres; sposoby radzenia sobie ze stresem; pielęgniarki; czynniki ryzyka; obciążenie pracą; środowisko pracy.

* Praca powstała dzięki wsparciu finansowemu Gdańskiego Uniwersytetu Medycznego ze środków ST 546 (przyznanych na lata 2012-2014). 


\section{WSTĘP}

Jednym z wielu czynników wpływających na zdrowie człowieka są warunki związane z wykonywaną przez niego pracą zawodową. Jeżeli są one dobre, praca staje się źródłem satysfakcji zawodowej i pozytywnie wpływa na kondycję pracowników. Stres jest nieodłącznym elementem pracy personelu medycznego w zakładach opieki zdrowotnej [1]. Zdaniem wielu badaczy praca personelu pielęgniarskiego nacechowana jest wyjątkowo wysokim poziomem stresu zawodowego [2,3]. W literaturze stres zawodowy rozpatrywany jest w wielu kategoriach [4] Jedna z definicji mówi o tym, że stres w życiu powstaje wskutek negatywnego oddziaływania środowiska na pracownika i z reguły ma on charakter mierzalny i obiektywny. Drugie podejście zakłada, że stres jest reakcją pracownika na szkodliwe warunki pracy. Trzecia teoria psychologiczna ujmuje stres jako interakcję pomiędzy środowiskiem pracy a pracownikiem, który w nim przebywa [5]. Pierwsze próby zbadania źródeł stresu w środowisku pracy oraz sposobów radzenia sobie z nim zostały opisane przez Lazarusa i Folkmana w 1984 r. Zgodnie z definicją badaczy stres należało rozumieć jako relację między osobą a otoczeniem, która oceniana jest przez osobę jako obciążająca lub przekraczająca jej zasoby i zagrażająca jej dobrostanowi [6]. Oczywiście poza charakterem i środowiskiem pracy nie bez znaczenia są właściwości psychologiczne jednostki, a także jej zdolność do radzenia sobie w sytuacjach stresowych [7].

Dotychczasowe wyniki badań z zakresu źródeł stresu personelu pielęgniarskiego wskazują na wielowymiarowość problemu. Praca personelu pielęgniarskiego należy bowiem do złożonych i trudnych. Niezbędne jest w niej posiadanie dużej sprawności manualnej przy wykonywanych zabiegach. Zakres obowiązków personelu pielęgniarskiego w ramach funkcjonowania oddziału szpitalnego jest duży. Obejmuje zazwyczaj czynności związane z prowadzeniem dokumentacji medycznej, obsługą sprzętu i urządzeń medycznych, zbieraniem wywiadu o stanie zdrowia pacjenta, prowadzeniem edukacji i promocji zdrowia, towarzyszeniem pacjentowi i jego rodzinie w chwilach trudnych związanych ze śmiercią $[8,9]$. Problem stresu w środowisku pracy personelu pielęgniarskiego nabiera znaczenia w kontekście coraz częstszych braków kadrowych oraz niedostatecznego wsparcia ze strony współpracowników i pracodawców [9].

Celem pracy była analiza specyficznych czynników stresogennych związanych z codzienną pracą personelu pielęgniarskiego wybranych oddziałów szpitalnych, a także zbadanie związku pomiędzy stresem a sposobami radzenia sobie z nim.

\section{MATERIAtY I METODY}

\section{Badana grupa}

Badanie przeprowadzono w jednym z trójmiejskich szpitali, za zgodą dyrektora placówki. Rozdano 200 kwestionariuszy wśród pielęgniarek zatrudnionych na różnych oddziałach szpitalnych, w tym: szpitalnym oddziale ratunkowych (SOR), oddziale anestezjologii i intensywnej terapii, chirurgii, kardiologii oraz internie. Do dalszej analizy statystycznej włączono jedynie 106 poprawnie uzupełnionych kwestionariuszy, co stanowiło $53 \%$ odpowiedzi. Udział w prowadzonym badaniu był dobrowolny i anonimowy, a każdą z pielęgniarek przystępująca do badania poinformowano, że wyniki zostaną wykorzystane tylko i wyłącznie do celów naukowych. Z badania wyłączono innych pracowników medycznych, w tym: lekarzy, fizjoterapeutów, ratowników medycznych, farmaceutów oraz dietetyków.

\section{Procedura prowadzonego badania}

Kwestionariusze ankiety były rozprowadzane przez członka zespołu badawczego. Każda z pielęgniarek przystępująca do badania otrzymywała wcześniej przygotowany zestaw, w skład którego wchodziły: list przewodni z instrukcją, kwestionariusz socjodemograficzny, Nursing Stress Scale (NNS) oraz Brief Cope-28 Scale, biała koperta. Każda z pielęgniarek mogła zwrócić wypełnione kwestionariusze ankiety w białej kopercie bezpośrednio członkowi zespołu badawczego lub pozostawić w specjalnie przygotowanym do tego celu pojemniku.

\section{Zgoda Komisji Bioetycznej}

Prowadzony projekt uzyskał zgodę Niezależnej Komisji Bioetycznej ds. Badań Naukowych przy Gdańskim Uniwersytecie Medycznym (nr: NKBBN/239/2012).

\section{Opis wykorzystanych narzędzi badawczych}

W prowadzonym projekcie do analizy specyficznych czynników stresogennych związanych z codzienną pracą personelu pielęgniarskiego wykorzystano wystandaryzowane narzędzie badawcze w postaci NNS. Drugą skalą służącą ocenie sposobów radzenia sobie w sytuacjach stresowych była Brief Cope-28 Scale. Autorzy skal NNS oraz Brief Cope-28 Scale wyrazili zgodę na wykorzystanie ich narzędzi badawczych w prowadzonym projekcie.

\section{Nursing Stres Scale}

Gray-Toft i Anderson [10] w autorskiej skali zawarli 34 twierdzenia dotyczące potencjalnie stresujących sytuacji w codziennej pracy personelu pielęgniarskiego. Zgodnie z oryginalnym kluczem odpowiedzi dokonuje się w oparciu o 4-stopniową skalę Likerta, gdzie stwierdzeniu „nigdy” przyporządkowano 1 pkt, natomiast „bardzo często” przypisano 4 pkt. Suma pkt uzyskanych poprzez zaznaczenie właściwej dla respondenta odpowiedzi wskazuje na stopień nasilenia postawy respondenta względem danego odczucia. Im wyższa liczba pkt, tym wyższy wskaźnik stresu. Poszczególne twierdzenia skali zgodnie z oryginalnym kluczem należało zaszeregować do jednego z 7 wskaźników sytuacji stresowych w pracy pielęgniarki, obejmujących zagadnienia: śmierci i umierania, sytuacji konfliktowych na linii pielęgniarka-lekarz, konfliktów pielęgniarkapielęgniarka, niedostatecznego przygotowania, braku wsparcia ze strony współpracowników i pracodawcy, obciążenia pracą oraz wątpliwości co do podejmowanej terapii diagnostycznej [10]. 


\section{Brief Cope-28 Scale}

Skala autorstwa profesora Charlesa S. Carvera z University of Miami jest jedną z najczęściej stosowanych skal służących ocenie sposobów radzenia sobie ze stresem, a pierwsze próby zbadania tego problemu wywodzą się z badań nad czynnikami stresogennymi. Brief Cope-28 Scale jest skróconą wersją skali COPE, która pozwala wyróżnić 14 technik zaradczych podzielonych na strategie adaptacyjne. Aktywne radzenie sobie w sytuacjach stresowych obejmuje: aktywne radzenie sobie ze stresem, planowanie, pozytywne przewartościowanie, akceptację, poczucie humoru, zwrot ku religii, poszukiwanie wsparcia społecznego i emocjonalnego. Zachowania nieadaptacyjne obejmują: wycofanie, zaprzeczenie, ekspresję emocji, nadużywanie substancji psychoaktywnych, poddawanie się, obwinianie się. Każde z 28 twierdzeń oceniane było w 4-stopniowej skali Likerta [11], która została przetłumaczona na wiele języków, w tym chiński, hiszpański, estoński. Brief Cope-28 Scale była wykorzystywana w wielu badaniach dotyczących sposobu radzenia sobie z sytuacją stresową u pacjentów z depresją, uzależnionych od leków, chorych onkologicznych, pacjentów z AIDS, studentów studiów medycznych [12].

\section{Analiza statystyczna}

Wszystkie obliczenia statystyczne wykonano w oparciu o program komputerowy IBM SPSS 20 oraz arkusz kalkulacyjny Excel. Do opisu struktury badanej populacji wykorzystano liczności oraz wartości procentowe (odsetek). Zmienne ilościowe scharakteryzowano za pomocą średniej arytmetycznej, odchylenia standardowego, mediany, wartości minimalnej i maksymalnej. Wnioskowania o zgodności wewnętrznej skal kwestionariusza dokonano, obliczając współczynnik zgodności Alfa Cronbacha. W celu stwierdzenia powiązania i siły pomiędzy poszczególnymi zmiennymi zastosowano analizę korelacji, obliczając współczynnik korelacji Spearmana. Istotność różnic zbadano testem U Manna-Whitneya, zaś istotność różnic pomiędzy więcej niż dwiema grupami sprawdzono testem Kurskala-Wallisa w przypadku niespełnienia warunków stosowalności testu ANOVA. We wszystkich obliczeniach za poziom istotności przyjęto $\mathrm{p}<0,05$.

\section{WYNIKI}

Dokładność pomiarową poszczególnych skal sprawdzono, obliczając współczynnik zgodności Alfa Cronbacha. Wynik dla poszczególnych skal kształtował się następująco: skala NNS $\alpha=0,925$, zaś skala Brief Cope-28 Scale $\alpha=0,806$. Uzyskane wyniki były zadowalające i oznaczały duże podobieństwo pomiędzy otrzymanymi odpowiedziami respondentów.

\section{Struktura socjodemograficzna badanych}

W prowadzonym badaniu wzięło udział 110 pielęgniarek kilku oddziałów szpitalnych. Do dalszej analizy statystycznej włączono 106 poprawnie uzupełnionych kwestionariuszy ankiet. Zdecydowaną większość badanych stanowiły kobiety (99,1\%).
TABELA 1. Charakterystyka społeczno-demograficzna badanej grupy badawczej

\begin{tabular}{|c|c|c|}
\hline Dane ogólne & $\mathrm{n}$ & $\%$ \\
\hline \multicolumn{3}{|l|}{ Płeć } \\
\hline kobieta & 105 & 99,1 \\
\hline \multicolumn{3}{|l|}{ Wiek } \\
\hline $22-30$ & 18 & 17,0 \\
\hline $31-40$ & 42 & 39,6 \\
\hline $41-50$ & 39 & 36,8 \\
\hline $51-57$ & 7 & 6,6 \\
\hline
\end{tabular}

\begin{tabular}{lll}
\hline Miejsce zamieszkania & & \\
\hline miasto & 91 & 85,8 \\
\hline wieś & 15 & 14,2 \\
\hline Stan cywilny & & \\
\hline w związku małżeńskim & 70 & 66,0 \\
\hline wolny & 36 & 34,0 \\
\hline
\end{tabular}

\begin{tabular}{lcc}
\hline Wykształcenie & & \\
\hline I $^{\circ}$ w dziedzinie pielęgniarstwa & 63 & 59,4 \\
\hline II $^{\circ}$ w dziedzinie pielęgniarstwa & 37 & 34,9 \\
\hline I $^{\circ}$ w innej dziedzinie & 1 & 0,9 \\
\hline II $^{\circ}$ w innej dziedzinie & 5 & 4,7 \\
\hline
\end{tabular}

\begin{tabular}{lcc}
\hline Stanowisko & & \\
\hline pielęgniarka odcinkowa & 96 & 90,6 \\
\hline pielęgniarka koordynująca & 3 & 2,8 \\
\hline pielęgniarka oddziałowa & 7 & 6,6 \\
\hline pielęgniarka przełożona & - & - \\
\hline inne & - & -
\end{tabular}

\begin{tabular}{ccc} 
inne & - & - \\
\hline Staż & & \\
\hline $1-5$ & 14 & 13,2 \\
\hline $6-10$ & 12 & 11,3 \\
\hline $11-15$ & 16 & 15,1 \\
\hline $16-20$ & 31 & 29,2 \\
\hline $21-25$ & 19 & 17,9 \\
\hline $26-30$ & 12 & 11,3 \\
\hline$>30$ & 2 & 1,9 \\
\hline Liczba zakładów & & \\
\hline 1 & 78 & 73,6 \\
\hline 2 & 26 & 24,5 \\
\hline 3 & 2 & 1,9
\end{tabular}

Forma zatrudnienia

\begin{tabular}{lcc}
\hline umowa o pracę & 98 & 92,5 \\
\hline umowa zlecenie & 3 & 2,8 \\
\hline kontrakt & 5 & 4,7 \\
\hline Wymiar czasu & & \\
\hline cały etat & 94 & 88,7 \\
\hline $1 / 2$ etatu & 1 & 0,9 \\
\hline limit godzinowy & 5 & 4,7 \\
\hline 2 etaty & 6 & 5,7
\end{tabular}


Można zatem przyjąć, że badana grupa była wewnętrznie jednorodna ze względu na płeć. Wiek respondentów mieścił się w granicach 22-57 lat. Najliczniejszą grupę $(n=42)$ stanowiły pielęgniarki w przedziale 31-40 lat, natomiast 36,8\% (n = 38) osoby w wieku 41-50 lat. Analiza struktury wykształcenia wykazała, że ponad 59,4\% (n = 63) to osoby, które ukończyły studia pielęgniarskie I stopnia, zaś $37(34,9 \%)$ respondentów deklarowało ukończenie studiów pielęgniarskich II stopnia. Grupa badanych pielęgniarek była wewnętrznie zróżnicowana ze względu na staż pracy w zawodzie. Najliczniejszą grupę $(29,2 \%)$ stanowił personel w przedziale 16-20 lat pracy. Drugą równie liczną grupą (17,9\%) były osoby pracujące średnio 21-25 lat w zawodzie. Ponad 90,6\% (n = 96) stanowił personel pielęgniarski zatrudniony na odcinku. Zdecydowana większość badanych respondentów deklarowała zatrudnienie w jednym zakładzie pracy $(73,6 \%)$ w formie umowy o pracę $(92,5 \%)$. Ponad $24,5 \%$ badanych pielęgniarek $(n=26)$ deklarowało zatrudnienie w dwóch zakładach pracy jednocześnie. Szczegółowe zestawienie struktury społeczno-demograficznej badanych przedstawiono w tabeli 1 .

\section{Czynniki stresogenne w codziennej pracy personelu pielęgniarskiego}

Uwzględniając średnie wartości punktowe poszczególnych odpowiedzi respondentów, spośród wielu czynników stresogennych w miejscu pracy największe źródło stresu personelu pielęgniarskiego stanowiły: śmierć i umieranie (M 19,11; SD $\pm 3,95$ ), obciążenie pracą zawodową ( 17,21 ; $S D \pm 3,52$ ), konflikt na linii pielęgniarka-lekarz (M 11,85; SD $\pm 2,95$ ), a także wątpliwości co do stosowanej terapii diagnostycznej (M 11,75, SD $\pm 3,15)$. Szczegółowe zestawienie przedstawiono w tabeli 2 . Analiza z wykorzystaniem korelacji Spearmana wykazała istnienie na granicy tendencji statystycznej związku pomiędzy stażem pracy a poziomem stresu badanych respondentów. Przeprowadzone badanie potwierdziło, że wraz ze wzrostem stażu pracy poziom stresu maleje ( $\mathrm{rHO}=-0,18 ; \mathrm{p}=0,0066)$. Analizy z wykorzystaniem testu U Manna-Whitneya potwierdziły istnienie zależności pomiędzy miejscem zamieszkania badanych respondentów a poziomem stresu. Badanie wykazało, że osoby zamieszkujące środowiska miejskie odznaczają się wyższym poziomem stresu w porównaniu z osobami mieszkającymi w środowisku wiejskim $(Z=-2,12 ; p=0,034)$. Dalsze analizy nie wykazały istotnych zależności pomiędzy poziomem stresu a wiekiem czy poziomem wykształcenia. Analiza

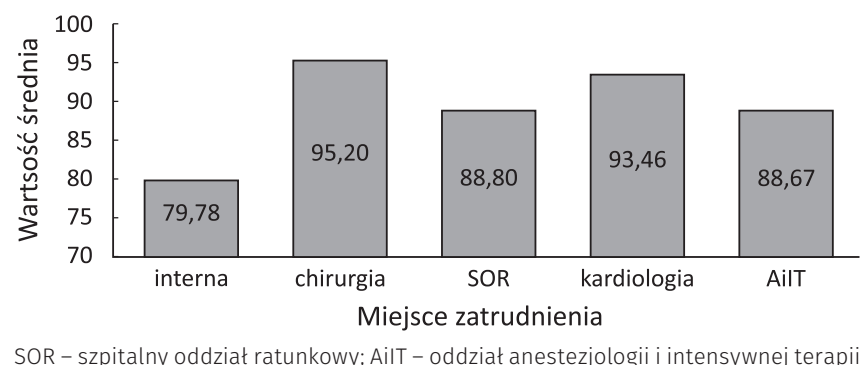

RYCINA 1. Średnie wartości poziomu stresu w zależności od miejsca zatrudnienia

z wykorzystaniem testu istotności Kurskala-Wallisa wykazała istotną statystycznie zależność pomiędzy poziomem stresu a miejscem zatrudnienia badanych respondentów $(H=13,99$; $\mathrm{p}=0,007$ ). Dalszą analizę wykonano za pomocą porównań wielokrotnych Bonferroniego, wykazując, że istotnie wyższy poziom stresu mają pielęgniarki pracujące na oddziale chirurgicznym i kardiologicznym w porównaniu z personelem pracującym na internie czy na oddziale intensywnej terapii (ryc. 1).

\section{Sposoby radzenia sobie ze stresem}

Uwzględniając średnie wartości punktowe poszczególnych odpowiedzi respondentów, wytypowano najczęstsze sposoby radzenia sobie ze stresem. W sytuacjach stresowych personel pielęgniarski najczęściej wykorzystuje: aktywne sposoby radzenia sobie ze stresem (M 5,91; SD $\pm 1,51$ ), wsparcie społeczne (M 5,12; $\mathrm{SD} \pm 1,65)$, pozytywne przewartościowanie (M 5,60; SD $\pm 1,53$ ), rozwiązywanie problemów poprzez planowanie (M 5,81; SD $\pm 1,37$ ) oraz akceptację problemów (M 5,55; SD $\pm 1,54)$ - tabela 2.

Analizy z wykorzystaniem testu korelacji Spermana wykazały istotny statystycznie związek pomiędzy wiekiem a radzeniem sobie ze stresem poprzez zachowanie wewnętrznego spokoju, a także między stażem pracy a obwinianiem się. Wykazano, że wiek ma duże znaczenie w technikach służących minimalizowaniu czynników stresogennych. Wraz ze wzrostem wieku częstsze staje się radzenie sobie ze stresem $\mathrm{w}$ formie wsparcia społecznego ( $\mathrm{rHO}=-0,25 ; \mathrm{p}=0,05)$, wsparcia instrumentalnego ( $\mathrm{rHO}=-0,25 ; \mathrm{p}<0,05$ ) oraz uciekania do spraw duchowych ( $\mathrm{rHO}=0,19 ; \mathrm{p}<0,05)$. W pozostałych sposobach radzenia sobie ze stresem nie uzyskano istotnego statystycznie związku pomiędzy zmiennymi. Dalsze badanie z wykorzystaniem testu U Manna-Whitneya wykazały istotne statystycznie zależności pomiędzy zmiennymi sposób radzenia sobie

TABELA 2. Statystyki opisowe dla zmiennych źródła stresu

\begin{tabular}{|c|c|c|c|c|c|}
\hline Źródła stresu & n & Min. & Maks. & M & SD \\
\hline Śmierć i umieranie & 106 & 11 & 28 & 19,11 & 3,95 \\
\hline Konflikty na linii pielęgniarka-lekarz & 106 & 7 & 20 & 11,85 & 2,94 \\
\hline Niedostateczne przygotowanie & 106 & 3 & 12 & 7,01 & 1,69 \\
\hline Brak wsparcia & 106 & 3 & 12 & 6,71 & 2,13 \\
\hline Konflikty na linii pielęgniarka-pielęgniarka & 106 & 5 & 20 & 11,82 & 3,48 \\
\hline Obciążenie pracą & 106 & 9 & 24 & 17,21 & 3,52 \\
\hline Wątpliwości co do terapii diagnostycznej & 106 & 5 & 20 & 11,75 & 3,15 \\
\hline
\end{tabular}

Min. - minimum; Maks. - maksimum; M - średnia; SD - odchylenie standardowe 
TABELA 3. Sposoby radzenia sobie ze stresem

\begin{tabular}{|c|c|c|c|c|c|}
\hline Radzenie sobie ze stresem & $\mathbf{n}$ & Min. & Maks. & M & SD \\
\hline Wewnętrzny spokój & 106 & 2 & 8 & 4,77 & 1,71 \\
\hline Aktywny sposób radzenia sobie & 106 & 2 & 8 & 5,91 & 1,51 \\
\hline Zaprzeczanie & 106 & 2 & 8 & 3,95 & 1,59 \\
\hline Używanie substancji psychoaktywnych & 106 & 2 & 6 & 2,26 & 0,68 \\
\hline Wykorzystanie wsparcia instrumentalnego & 106 & 2 & 8 & 5,16 & 1,53 \\
\hline Behawioralne wycofanie & 106 & 2 & 8 & 4,64 & 1,32 \\
\hline Dawanie upustu swoim emocjom & 106 & 2 & 8 & 4,91 & 1,68 \\
\hline Pozytywne przewartościowanie & 106 & 2 & 8 & 5,60 & 1,53 \\
\hline Rozwiązywanie problemów przez planowanie & 106 & 2 & 8 & 5,81 & 1,37 \\
\hline Akceptacja & 106 & 2 & 8 & 5,55 & 1,54 \\
\hline Uciekanie do spraw duchowych & 106 & 2 & 8 & 4,58 & 1,94 \\
\hline Obwinianie się & 106 & 2 & 8 & 4,52 & 1,53 \\
\hline
\end{tabular}

n - liczebność; Min. - minimum; Maks. - maksimum; M - średnia; SD - odchylenie standardowe

ze stresem a sytuacją rodzinną. Osoby wolne istotnie częściej jako sposobu radzenia sobie ze stresem używały wsparcia społecznego $(\mathrm{Z}=-2,16 ; \mathrm{p}<0,05)$ oraz spokoju wewnętrznego $(\mathrm{Z}=-2,43 ; \mathrm{p}<0,05) \mathrm{w}$ porównaniu $\mathrm{z}$ respondentami będącymi w związku małżeńskim. Przeprowadzone badanie potwierdziło, że sposób radzenia sobie w sytuacjach stresowych zależy od miejsca zamieszkania. Respondenci zamieszkujący miasto istotnie częściej radzili sobie ze stresem poprzez planowanie $(\mathrm{Z}=-2,17 ; \mathrm{p}<0,05)$. Analiza z wykorzystaniem testu U MannaWhitneya potwierdziła, że osoby zamieszkujące środowiska miejskie zdecydowanie częściej wykorzystują radzenie sobie ze stresem poprzez wewnętrzny spokój $\left(\mathrm{H}_{(4)}=10,68 ; \mathrm{p}<0,05\right)$, dawanie upustu emocjom $\left(\mathrm{H}_{(4)}=14,68 ; \mathrm{p}<0,05\right)$, planowanie $(\mathrm{Z}=-2,17 ; \mathrm{p}<0,05)$ oraz - na granicy tendencji statystycznej - poprzez żartowanie $\left(\mathrm{H}_{(4)}=10,68 ; \mathrm{p}=0,060\right)$. Szczegółowe analizy pokazały, że w sytuacji dużego poziomu stresu, jego ciągłego narastania, częstszy staje się sposób radzenia sobie ze stresem poprzez wycofanie $(\mathrm{rHO}=0,59 ; \mathrm{p}=0,000)$. Aby sprawdzić, pomiędzy którymi grupami zachodzi istotna statystycznie zależność, zastosowano metodę porównań wielokrotnych Bonferroniego. Uzyskane wyniki wykazały, że personel pielęgniarski oddziału anestezjologii i intensywnej terapii statystycznie częściej jako sposób radzenia sobie w sytuacji stresowej wykorzystuje technikę wewnętrznego spokoju. Personel pielęgniarski pracujący na oddziałach chirurgii wykorzystuje technikę redukowania stresu w formie wewnętrznego spokoju oraz dawania upustu emocjom (tab. 3 i 4).

\section{OMÓWIENIE I DYSKUSJA}

Przeprowadzone badanie własne pozwoliło na identyfikację najbardziej stresogennych czynników w pracy personelu pielęgniarskiego. Szczegółowe analizy zgromadzonego materiału potwierdziły wysoki wskaźnik poziomu stresu w kategorii śmierć i umieranie. Zdaniem Steinhauser i wsp. może to mieć związek z niewystarczającym przygotowaniem personelu medycznego do tak dużego obciążenia psychicznego, jakim jest śmierć [13]. Z piśmiennictwa wynika, że śmierć jest wciąż w wielu krajach i kulturach tematem tabu, a opieka nad pacjentem umierającym stanowi duże wyzwanie [14]. Pielęgniarki w czasie opieki nad pacjentem umierającym dostrzegają znaczenie i wagę swojej obecności, niemniej jednak nie zawsze czują się do tego dobrze przygotowane. Wyniki badań, które przeprowadzili Ryan i Jezewski, potwierdzają, że ponad 60\% pielęgniarek czuje się niepewnie w świadczeniu opieki nad pacjentem umierającym [15]. Największy poziom stresu i obaw deklarują pielęgniarki oddziału ratunkowego i intensywnej terapii.

Kolejnym czynnikiem stresogennym w codziennej pracy personelu pielęgniarskiego są konflikty na linii pielęgniarkalekarz oraz znaczne obciążenie pracą. Problem braku właściwej komunikacji pomiędzy pielęgniarką a lekarzem został wskazany w wielu publikacjach naukowych [16] i może wynikać z poszerzania zakresu obowiązków zawodowych personelu pielęgniarskiego. W przeprowadzonym projekcie własnym personel pielęgniarski zidentyfikował konflikty pomiędzy lekarzami a pielęgniarkami jako jedno z istotnych źródeł stresu w pracy zawodowej. Wysoka punktacja przy tym wskaźniku może mieć związek z poziomem wykształcenia badanych respondentów. Zmiany w systemie kształcenia personelu pielęgniarskiego, podyktowane dążeniem do ujednolicenia kompetencji zawodowych personelu pielęgniarskiego w ramach krajów Unii Europejskiej, doprowadzają do wzrostu poczucia samodzielności zawodowej i poprawy umiejętności klinicznych. Analiza dotychczasowego piśmiennictwa wyraźnie pokazuje, że dobre przygotowanie teoretyczne personelu pielęgniarskiego, edukacja na poziomie studiów pielęgniarskich lub innego kształcenia podyplomowego przekłada się na wzrost świadomości i umiejętności personelu pielęgniarskiego [17]. Wykształcenie ma również silny związek z wykorzystywaniem przez 
TABELA 4. Sposób radzenia sobie ze stresem a miejsce zatrudnienia

\begin{tabular}{|c|c|c|c|c|}
\hline $\begin{array}{c}\text { Sposoby radzenia sobie } \\
\text { ze stresem }\end{array}$ & $\begin{array}{c}\text { Miejsce } \\
\text { zatrudnienia }\end{array}$ & $\mathbf{n}$ & $M$ & SD \\
\hline $\begin{array}{l}\text { Wewnętrzny } \\
\text { spokój }\end{array}$ & $\begin{array}{l}\text { interna } \\
\text { chirurgia } \\
\text { SOR } \\
\text { kardiologia } \\
\text { AilT }\end{array}$ & $\begin{array}{c}55 \\
5 \\
10 \\
24 \\
12\end{array}$ & $\begin{array}{l}4,42 \\
6,20 \\
4,90 \\
4,71 \\
5,83\end{array}$ & $\begin{array}{l}1,67 \\
0,84 \\
2,02 \\
1,43 \\
1,85\end{array}$ \\
\hline $\begin{array}{l}\text { Aktywny sposób } \\
\text { radzenia sobie }\end{array}$ & $\begin{array}{l}\text { interna } \\
\text { chirurgia } \\
\text { SOR } \\
\text { kardiologia } \\
\text { AilT }\end{array}$ & $\begin{array}{c}55 \\
5 \\
10 \\
24 \\
12\end{array}$ & $\begin{array}{l}5,89 \\
6,20 \\
5,30 \\
5,75 \\
6,67 \\
\end{array}$ & $\begin{array}{l}1,55 \\
2,49 \\
1,77 \\
1,15 \\
1,15\end{array}$ \\
\hline Zaprzeczanie & $\begin{array}{l}\text { interna } \\
\text { chirurgia } \\
\text { SOR } \\
\text { kardiologia } \\
\text { AilT }\end{array}$ & $\begin{array}{c}55 \\
5 \\
10 \\
24 \\
12 \\
\end{array}$ & $\begin{array}{l}3,76 \\
5,20 \\
3,70 \\
4,00 \\
4,42 \\
\end{array}$ & $\begin{array}{l}1,55 \\
1,48 \\
1,64 \\
1,62 \\
1,68\end{array}$ \\
\hline $\begin{array}{l}\text { Używanie substancji } \\
\text { psychoaktywnych }\end{array}$ & $\begin{array}{l}\text { interna } \\
\text { chirurgia } \\
\text { SOR } \\
\text { kardiologia } \\
\text { AilT }\end{array}$ & $\begin{array}{c}55 \\
5 \\
10 \\
24 \\
12 \\
\end{array}$ & $\begin{array}{l}2,29 \\
2,00 \\
2,10 \\
2,29 \\
2,33 \\
\end{array}$ & $\begin{array}{l}0,76 \\
0,00 \\
0,32 \\
0,69 \\
0,65\end{array}$ \\
\hline $\begin{array}{l}\text { Używanie wsparcia } \\
\text { społecznego }\end{array}$ & $\begin{array}{l}\text { interna } \\
\text { chirurgia } \\
\text { SOR } \\
\text { kardiologia } \\
\text { AilT }\end{array}$ & $\begin{array}{c}55 \\
5 \\
10 \\
24 \\
12\end{array}$ & $\begin{array}{l}4,89 \\
4,80 \\
5,10 \\
5,46 \\
5,67 \\
\end{array}$ & $\begin{array}{l}1,72 \\
1,92 \\
1,91 \\
1,53 \\
1,15\end{array}$ \\
\hline $\begin{array}{l}\text { Wykorzystywanie } \\
\text { wsparcia } \\
\text { instrumentalnego }\end{array}$ & $\begin{array}{l}\text { interna } \\
\text { chirurgia } \\
\text { SOR } \\
\text { kardiologia } \\
\text { AilT }\end{array}$ & $\begin{array}{c}55 \\
5 \\
10 \\
24 \\
12\end{array}$ & $\begin{array}{l}5,07 \\
5,60 \\
5,30 \\
5,21 \\
5,17\end{array}$ & $\begin{array}{l}1,53 \\
1,67 \\
2,16 \\
1,44 \\
1,27\end{array}$ \\
\hline $\begin{array}{l}\text { Behawioralne } \\
\text { wycofanie }\end{array}$ & $\begin{array}{l}\text { interna } \\
\text { chirurgia } \\
\text { SOR } \\
\text { kardiologia } \\
\text { AilT }\end{array}$ & $\begin{array}{c}55 \\
5 \\
10 \\
24 \\
12 \\
\end{array}$ & $\begin{array}{l}4,33 \\
5,00 \\
5,00 \\
5,08 \\
4,75 \\
\end{array}$ & $\begin{array}{l}1,16 \\
0,71 \\
1,63 \\
1,50 \\
1,36\end{array}$ \\
\hline $\begin{array}{l}\text { Dawanie upustu } \\
\text { swoim emocjom }\end{array}$ & $\begin{array}{l}\text { interna } \\
\text { chirurgia } \\
\text { SOR } \\
\text { kardiologia } \\
\text { AilT }\end{array}$ & $\begin{array}{c}55 \\
5 \\
10 \\
24 \\
12 \\
\end{array}$ & $\begin{array}{l}4,56 \\
7,00 \\
4,30 \\
5,08 \\
5,75 \\
\end{array}$ & $\begin{array}{l}1,68 \\
1,00 \\
1,64 \\
1,47 \\
1,54\end{array}$ \\
\hline $\begin{array}{l}\text { Pozytywne } \\
\text { przewartościowanie }\end{array}$ & $\begin{array}{l}\text { interna } \\
\text { chirurgia } \\
\text { SOR } \\
\text { kardiologia } \\
\text { AilT }\end{array}$ & $\begin{array}{c}55 \\
5 \\
10 \\
24 \\
12\end{array}$ & $\begin{array}{l}5,69 \\
5,60 \\
5,90 \\
5,04 \\
6,08\end{array}$ & $\begin{array}{l}1,48 \\
2,30 \\
1,91 \\
1,46 \\
1,16\end{array}$ \\
\hline $\begin{array}{l}\text { Rozwiązywanie } \\
\text { problemów } \\
\text { przez planowanie }\end{array}$ & $\begin{array}{l}\text { interna } \\
\text { chirurgia } \\
\text { SOR } \\
\text { kardiologia } \\
\text { AilT }\end{array}$ & $\begin{array}{c}55 \\
5 \\
10 \\
24 \\
12\end{array}$ & $\begin{array}{l}5,65 \\
6,40 \\
6,10 \\
5,71 \\
6,25\end{array}$ & $\begin{array}{l}1,32 \\
2,61 \\
1,79 \\
0,95 \\
1,29\end{array}$ \\
\hline $\begin{array}{l}\text { Obracanie } \\
\text { w żart }\end{array}$ & $\begin{array}{l}\text { interna } \\
\text { chirurgia } \\
\text { SOR } \\
\text { kardiologia } \\
\text { AilT }\end{array}$ & $\begin{array}{c}55 \\
5 \\
10 \\
24 \\
12\end{array}$ & $\begin{array}{l}3,33 \\
5,40 \\
3,00 \\
3,67 \\
3,92 \\
\end{array}$ & $\begin{array}{l}1,48 \\
1,67 \\
1,70 \\
1,31 \\
2,15\end{array}$ \\
\hline Akceptacja & $\begin{array}{l}\text { interna } \\
\text { chirurgia } \\
\text { SOR } \\
\text { kardiologia } \\
\text { AilT }\end{array}$ & $\begin{array}{c}55 \\
5 \\
10 \\
24 \\
12\end{array}$ & $\begin{array}{l}5,42 \\
5,60 \\
6,20 \\
5,33 \\
6,00\end{array}$ & $\begin{array}{l}1,57 \\
1,67 \\
1,40 \\
1,52 \\
1,48\end{array}$ \\
\hline $\begin{array}{l}\text { Uciekanie } \\
\text { do spraw duchowych }\end{array}$ & $\begin{array}{l}\text { interna } \\
\text { chirurgia } \\
\text { SOR } \\
\text { kardiologia } \\
\text { AilT }\end{array}$ & $\begin{array}{c}55 \\
5 \\
10 \\
24 \\
12\end{array}$ & $\begin{array}{l}4,71 \\
4,60 \\
4,60 \\
4,38 \\
4,42\end{array}$ & $\begin{array}{l}1,81 \\
2,07 \\
2,27 \\
1,95 \\
2,43\end{array}$ \\
\hline Obwinianie się & $\begin{array}{l}\text { interna } \\
\text { chirurgia } \\
\text { SOR } \\
\text { kardiologia } \\
\text { AilT }\end{array}$ & $\begin{array}{c}55 \\
5 \\
10 \\
24 \\
12\end{array}$ & $\begin{array}{l}4,58 \\
4,60 \\
4,20 \\
4,38 \\
4,75\end{array}$ & $\begin{array}{l}1,57 \\
1,95 \\
1,62 \\
1,41 \\
1,48\end{array}$ \\
\hline
\end{tabular}

n - liczebność; M - średnia; SD - odchylenie standardowe; SOR - szpitalny oddział ratunkowy; AilT - oddział anestezjologii i intensywnej terapii personel pielęgniarski badań naukowych w codziennej praktyce klinicznej [18].

Innym równie istotnym źródłem stresu personelu pielęgniarskiego jest nadmierne obciążenie w pracy. Biorąc pod uwagę narastające braki kadry pielęgniarskiej oraz poszerzenie zakresu obowiązków zawodowych personelu pielęgniarskiego, zjawisko nadmiernego przeciążenia w pracy jest problemem coraz bardziej zauważalnym i dotkliwym [19]. Przegląd dotychczasowych badań naukowych pokazuje, że nadmierne obciążenie w pracy dotyczy różnych specjalności pielęgniarskich $[19,20]$ i jest jednym z głównych czynników, które wpływają na jakość opieki [21] czy występowanie zdarzeń niepożądanych [22]. W badaniach własnych wykazano istotną zależność pomiędzy poziomem stresu a stażem pracy i wiekiem badanych respondentów. Wyniki analizy są zbliżone do innych naukowców. Winwood i wsp. udowodnili, że personel pielęgniarski z dłuższym stażem zawodowym odczuwa znacznie mniejsze zmęczenie i stres w pracy zawodowej. Autorzy potwierdzili, że personel pielęgniarski mający dłuższe doświadczenie zawodowe znacznie szybciej przystosowuje się do zmieniających się warunków pracy, jak również zdecydowanie łatwiej radzi sobie ze stresem [23]. W realizowanym projekcie własnym nie wykazano istotnych statystycznie zależności pomiędzy poziomem stresu a zajmowanym stanowiskiem, sytuacją rodzinną oraz wymiarem czasu pracy. Uzyskane wyniki różnią się od wyników innych autorów. Analizy przeprowadzone przez Shena i wsp. wykazały, że pielęgniarki będące wdowami lub rozwódkami mają wyższy poziom stresu w porównaniu z pielęgniarkami będącymi w związku małżeńskim [24]. W innych badaniach wskazano na istnienie związku pomiędzy poziomem stresu zawodowego a posiadaniem dzieci [8].

Personel pielęgniarski w codziennej opiece nad pacjentem niejednokrotnie jest świadkiem tego, że mimo podejmowanych heroicznych wysiłków zmierzających do wyleczenia, zdarza się, że stan pacjenta z dnia na dzień ulega pogorszeniu. Problem tzw. uporczywych terapii jest dość szeroko omawiany w literaturze przedmiotu. Pielęgniarki niejednokrotnie zwracały uwagę na podejmowanie agresywnych terapii u chorych nierokujących [25]. Lekarze są odpowiedzialni za podejmowane decyzje dotyczące metod leczenia i terapii pacjenta [16], natomiast $\mathrm{w}$ procesie tym bardzo rzadko formalnie uczestniczy personel pielęgniarski, którego jednym z głównych zadań jest opieka i pielęgnacja pacjenta [26]. W przeprowadzonym badaniu własnym potwierdzono, że dużym źródłem stresu dla personelu pielęgniarskiego jest wciąż brak zrozumienia oraz wątpliwości w zakresie podejmowanych działań terapeutycznych.

Stwierdzono istnienie zależności pomiędzy poziomem stresu a miejscem zatrudnienia. Najwyższy poziom stresu był związany z oddziałem chirurgii oraz kardiologii. Na drugim miejscu znalazł się oddział anestezjologii i intensywnej terapii oraz szpitalny oddział ratunkowy. Uzyskane wyniki różnią się od wyników innych autorów. Callaghan i wsp. wykazali, że poziom stresu personelu pielęgniarskiego oddziałów pediatrycznych jest zdecydowanie wyższy w porwaniu z oddziałami położniczymi czy psychiatrycznymi [27]. 
W innych doniesieniach naukowych udowodniono, że natężenie stresu personelu pielęgniarskiego oddziałów ratunkowych czy intensywnej terapii jest zdecydowanie wyższe w porównaniu z pozostałymi oddziałami szpitalnymi [28]. Otrzymane różnice w uzyskanych wynikach badań własnych mogą mieć związek z odmiennym profilem medycznym oddziałów. Innym równie istotnym problemem jest wciąż nieuregulowana kwestia minimalnych norm zatrudniania personelu pielęgniarskiego w placówkach ochrony zdrowia. Obecnie takie normy dotyczą tylko i wyłącznie oddziałów anestezjologii i intensywnej terapii oraz oddziałów neonatologicznych. Zgodnie z rozporządzeniem Ministra Zdrowia z 20 grudnia 2012 r. stosunek liczby pielęgniarek anestezjologicznych w sali nadzoru poznieczuleniowego na każdej zmianie do liczby faktycznie obłożonych stanowisk wynosi 1:4 [29]. Rozporządzenie pozwoliło określić również trzy poziomy intensywności opieki pielęgniarskiej na oddziale intensywnej terapii, gdzie najwyższy stopień opieki dotyczy pacjenta z niewydolnością co najmniej dwóch lub więcej układów/narządów i powinien wiązać się z opieką jednej pielęgniarki na stanowisko intensywnej terapii na zmianę. Braki w rozwiązaniach systemowych na innych oddziałach zabiegowych mogą znacząco przekładać się na poziom odczuwanego stresu personelu pielęgniarskiego, na co wyraźnie wskazują wyniki badań własnych.

Przeprowadzona analiza pozwoliła bliżej zbadać techniki radzenia sobie w sytuacjach stresogennych. W zgromadzonym materiale potwierdzono, że personel pielęgniarski bardzo często w celu minimalizowania czynników stresogennych wykorzystuje wsparcie społeczne, instrumentalne, pozytywne przewartościowanie oraz uciekanie do spraw duchowych. Szczegółowe analizy potwierdziły, że „wycofanie się” oraz „ucieczka” mają związek z wysokim natężeniem czynnika stresogennego. Wyniki uzyskane w prowadzonym projekcie są zbliżone do wyników innych autorów. Ceslowitz wykorzystał skale Lazarusa do oceny sposobu radzenia sobie ze stresem, co wyraźnie wskazało, że personel pielęgniarski, narażony na występowanie wypalenia zawodowego, zdecydowanie częściej wykorzystuje technikę ucieczki oraz unikania [30]. Pielęgniarki obarczone niskim wskaźnikiem wypalenia zawodowego w sytuacjach trudnych wykorzystują planowanie, pozytywne przewartościowanie oraz wsparcie społeczne. W piśmiennictwie potwierdzono również, że sposób radzenia sobie z sytuacją stresogenną może wynikać nie tylko z właściwości psychologicznych jednostki, ale bardzo często jest też uwarunkowany kulturowo. Lampert i wsp. [2] stwierdzili, że personel pielęgniarski pracujący w Korei zdecydowanie częściej w minimalizowaniu stresu wykorzystuje pozytywne przewartościowanie, podczas gdy pielęgniarki w Japonii najczęściej stosują wewnętrzny spokój oraz kontrolę. Zupełnie odmienny styl radzenia sobie z sytuacją stresogenną prezentują pielęgniarki amerykańskie, które odwołują się głównie do aktywnego sposobu rozwiązywania problemu poprzez planowanie oraz obracanie trudnej sytuacji w żart [2]. Przeprowadzone badanie własne pozwoliło na wytypowanie technik minimalizowania stresu na wybranych oddziałach szpitalnych. Dokładniejsze analizy potwierdziły, że personel oddziałów anestezjologii czy chirurgii zmniejsza stres poprzez zachowywanie wewnętrznego spokoju. Brak szczegółowych wyników badań dotyczących technik radzenia sobie w sytuacjach stresogennych w odniesieniu do konkretnych oddziałów szpitalnych w Polsce stanowi trudność w interpretacji uzyskanych wyników przeprowadzonego projektu.

\section{WNIOSKI}

1. Praca personelu pielęgniarskiego nacechowana jest wysokim poziomem stresu. Do najbardziej stresogennych czynników należą: śmierć i umieranie, obciążenie pracą zawodową, konflikty na linii pielęgniarka-lekarz oraz wątpliwości co do stosowanej terapii.

2. Poziom stresu zależy od stażu pracy, miejsca zamieszkania oraz miejsca pracy. Personel pielęgniarski z oddziałów chirurgii i kardiologii odznacza się zdecydowanie wyższym poziomem stresu w porównaniu z tym z interny czy anestezjologii.

3. W sytuacjach stresogennych personel pielęgniarski najczęściej wykorzystuje: aktywne sposoby radzenia sobie ze stresem, używanie wsparcia społecznego, pozytywne przewartościowanie, rozwiązywanie problemów poprzez planowanie oraz akceptację.

4. Wraz ze wzrostem wieku badanych wzrasta poziom radzenia sobie w sytuacjach stresogennych poprzez wsparcie społeczne, instrumentalne oraz uciekanie do spraw duchowych.

5. Personel anestezjologiczny w mechanizmie radzenia sobie z sytuacjami stresującymi wykorzystuje wewnętrzny spokój. Personel pielęgniarski zatrudniony na oddziale chirurgii bardzo często stosuje formę minimalizowania stresu poprzez upust emocji.

6. Należy podjąć odpowiednie kroki do ograniczania czynników stresogennych w środowisku pracy personelu pielęgniarskiego. Niektóre z czynników mogą być bardzo łatwo modyfikowane poprzez wewnętrzne działania placówki medycznej, organizowanie wspólnych szkoleń, grup wsparcia lub zatrudnienie psychologa dla potrzeb pracowników medycznych.

\section{PIŚMIENNICTWO}

1. Yates $\mathrm{P}, \mathrm{Benson} \mathrm{E}$, Harris A. An investigation of factors supporting the psychological health of staff in a UK emergency department. Emerg Med I 2012;29:533-5

2. Lambert V, Lambert CE, Itano J, Inouye J, Kim S, Kuniviktikul W, et al. Crosscultural comparison of workplace stressors, ways of coping and demographic characteristics as predictors of physical and mental health among hospital nurses in Japan, Thailand, South Korea and the USA (Hawaii). Int J Nurs Stud 2004;41:671-84.

3. Ulrich CM, Taylor C, Soeken K, O'Donnell P, Farrar A, Danis M, et al. Everyday ethics: ethical issues and stress in nursing practice. J Adv Nurs 2010;66:2510-9.

4. European Agency for Safety and Health at Work. Expert forecast on emerging psychosocial risks related to occupational safety and health. Luxembourg: Office for Official Publications of the European Communities; 2007.

5. Cox T, Griffiths A, Rial-González E. Research on work related stress. Luxembourg: Office for Official Publications of the European Communities; 2000. 
6. Lazarus RS, Folkman S. Stress, appraisal and coping. New York: Springer; 1989.

7. Olofsson B, Bengtsson C, Brink E. Absence of response: a study of nurses experience of stress in the workplace. J Nurs Manag 2003;11:351-8.

8. Zhou H, Gong Y. Relationship between occupational stress and coping strategy among operating theatre nurses in China: a questionnaire survey. J Nurs Manag 2015;23:96-106.

9. Carayon P, Gurses A. A human factors engineering conceptual framework of nursing workload and patients' safety in intensive care units. Intensive Crit Care Nurs 2005;21:284-301.

10. Gray-Toft P, Anderson JG. The Nursing Stress Scale: Development of an instrument. J Behav Assessment 1981;3(1):11-23.

11. Carver CS. You want to measure coping but your protocol's too long: consider brief cope. Int J Behav Med 1997;4(1):92-100.

12. Szkup-Jabłońska M, Polakiewicz P, Schneider-Matyka D, Jurczak A, Stanisławska M, Wieder-Huszla S, et al. Analiza stresu związanego z akulturacją oraz strategii radzenia sobie ze stresem wśród studentów English Program Pomorskiego Uniwersytetu Medycznego w Szczecinie. Probl Pielęg 2014;22(1):74-81.

13. Steinhauser KE, Christakis NA, Clipp EC, McNeilly M, Grambow S, Parker J, et al. Preparing for the end of life: preferences of patients, families, physicians, and other care providers. J Pain Symptom Manage 2001;22:727-37.

14. Zheng RS, Guo QH, Dong FQ, Owens RG. Chinese oncology nurses' experience on caring for dying patients who are on their final days: a qualitative study. Int J Nurs Stud 2015;52,288-96.

15. Ryan D, Jezewski MA. Knowledge, attitudes, experiences, and confidence of nurses in completing advance directives: a systematic synthesis of three studies. J Nurs Res 2012;20:131-41.

16. Wujtewicz M, Wujtewicz MN, Owczuk R. Conflicts in the intensive care unit. Anaesthesiol Intensive Ther 2015;47:360-2.

17. Moore P. Decision-making in professional practice. Br J Nurs 1996;5:635-40.

18. Mehrdad N, Joolaee S, Joulaee A, Bahrani N. Nursing faculties' knowledge and attitude on evidence-based practice. Iran J Nurs Midwifery Res 2012;17(7):506-11.
19. Jackson A, Carberry M. The advance nurse practitioner in critical care: A workload evaluation. Nurs Crit Care 2015;20:71-7. doi: 10.1111/ nicc.12133.

20. Nishizaki Y, Tokuda Y, Sato E, Kato K, Matsumoto A, Takekata M, et al. Relationship between nursing workloads and patient safety incidents. J Multidiscip Healthc 2010;3:49-54.

21. Aiken LH, Clarke SP, Sloane DM, Sochalski J, Silber JH. Hospital nurse staffing and patient mortality, nurse burnout, and job dissatisfaction. JAMA 2002;288:1987-93.

22. Needleman J, Buerhaus P, Mattke S, Stewart M, Zelevinsky K. Nurse-staffing levels and the quality of care in hospitals. N Engl J Med 2002;346:1715-22.

23. Winwood PC, Winefield AH, Lushington K. Work-related fatigue and recovery: the contribution of age, domestic responsibilities and shiftwork. J Adv Nurs 2006;56:438-49.

24. Shen HC, Cheng Y, Tsai PJ, Lee SH, Guo YL. Occupational stress in nurses in psychiatric institutions in Taiwan. J Occup Health 2005;47(3):218-55.

25. Seymour JE. Negotiating natural death in intensive care. Soc Sci Med 2000;51(8):1241-52.

26. Ferrand E, Lemaire F, Regnier B, Kuteifan K, Badet M, Asfar P, et al. Discrepancies between perceptions by physicians and nursing staff of intensive care unit end-of-life decisions. Am J Respir Crit Care Med 2003;167: 1310-5.

27. Callaghan $\mathrm{P}$, Tak-Ying SA, Wyatt PA. Factors related to stress and coping among Chinese nurses in Hong Kong. J Adv Nurs 2000;31(6):1518-27.

28. Yang Y, Koh D, Ng V, Lee FC, Chan G, Dong F, et al. Salivary cortisol levels and work-related stress among emergency department nurses. J Occup Environ Med 2001;43(12):1011-8.

29. Rozporządzenie Ministra Zdrowia z dnia 20 grudnia 2012 roku w sprawie standardów postępowania medycznego w dziedzinie anestezjologii i intensywnej terapii dla podmiotów wykonujących działalność leczniczą. DzU RP z 2013 r., poz. 15. http://dziennikustaw.gov.pl/DU/2013/0015 (1.01.2017).

30. Ceslowitz SB. Burnout and coping strategies among hospital staff nurses. J Adv Nurs 1989;14:553-7. 